\title{
Challenges to nature conservation with community development in central African forests
}

\author{
Andrew J. Noss
}

\begin{abstract}
Based on field research in the Central African Republic, this article discusses several social and economic challenges to conservation programmes that include community development components. These interrelated challenges include immigration as people elsewhere are attracted to economic opportunities, the lack of tenure of land and natural resources, diversification of economic and subsistence strategies, ethnic diversity and the lack of a conservation ethic. Addressing these challenges requires fundamental socio-economic change.
\end{abstract}

\section{Introduction}

In order to achieve their objectives throughout the tropics, conservation organizations have increasingly sought to integrate economic development components with conservation projects. Two popular and widely promoted models are the integrated conservation and development project (ICDP) and communitybased conservation. Integrated conservation and development projects include protected areas that are managed with the co-operation and support of local people, as well as social and economic development projects to provide alternatives to natural resource use (Brandon and Wells, 1992; Barrett and Arcese, 1995). Likewise, community conservation is defined as natural resource conservation by, for and with local people, often seeking to provide economic improvements through conservation (Western and Wright, 1994). This paper treats these two similar models together. Both assume that nature conservation is impossible without the support and active participation of local residents. In addition, both promote community development as a means of encouraging local support, ensuring that economic development activities are ecologically sustainable, and providing subsistence and economic alternatives to unsustainable natural resource exploitation.
However, numerous researchers who have examined the implementation of these programmes question the compatibility of conservation and development (Brandon and Wells, 1992; Stocking and Perkin, 1992; Wells et al., 1992; Southgate and Clark, 1993; Barrett and Arcese, 1995; Gibson and Marks, 1995; Oates, 1995). This article discusses fundamental challenges to conservation efforts linked with community development programmes in central African forests, based on a hunting study (Noss, 1995) in the Dzanga-Ndoki National Park and Dzanga-Sangha Special Reserve of the Central African Republic (CAR). The headquarters of the ICDP, currently administered by the World Wildlife Fund US, are in the town of Bayanga (Figure 1). The challenges posed by immigration, lack of resource tenure, economic diversification, ethnic diversity and the lack of a conservation ethic are particularly relevant for the forest zone of Africa, but have implications for conservation and development efforts elsewhere.

\section{Immigration}

In many African countries formal employment opportunities are extremely scarce, and human residential and occupational mobility are high. Individuals pursue economic () $1997 \mathrm{FFl}$, Oryx, 31 (3), 180-188 
Figure 1. The Dzanga-Ndoki National Park and DzangaSangha Special Reserve, Central African Republic.

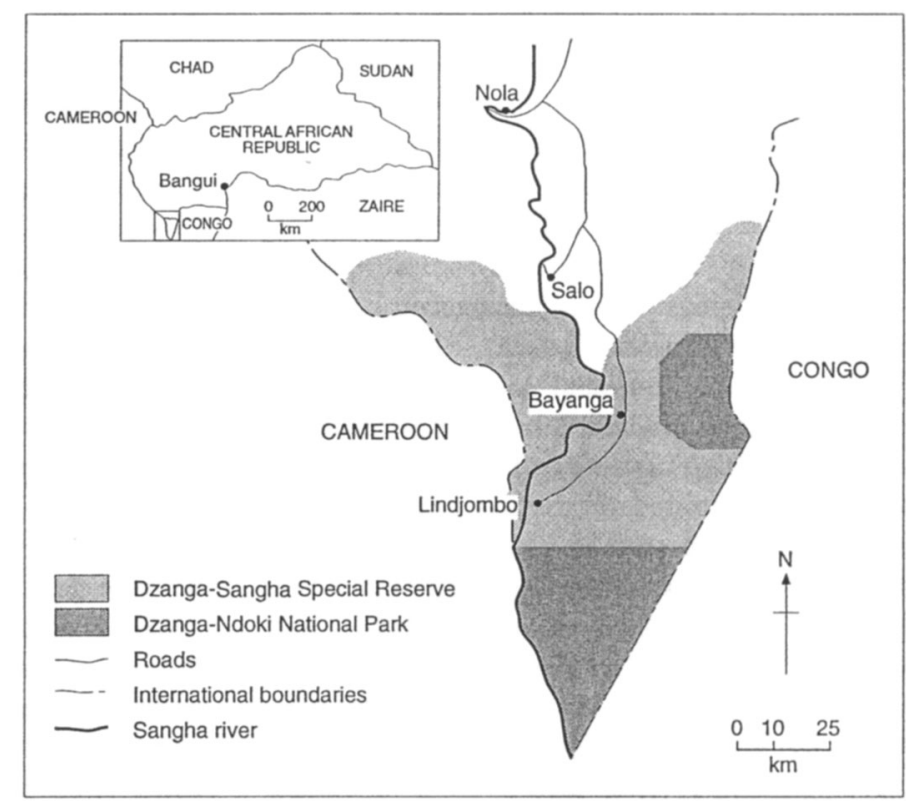

opportunities hundreds of kilometres from their homes, even in neighbouring countries. Economic development of any kind - a logging company, a conservation project - that offers employment, builds roads and provides services attracts migrants to the area (Stocking and Perkin, 1992; Wells et al., 1992). Workers are accompanied by their families, and extended family members often join employed individuals who can support them while they, too, seek work. Thus, 85 per cent of Bayanga's 2500 adult residents were born elsewhere, and many have worked in neighbouring Congo and Cameroon.

Starting in 1972, people were attracted to Bayanga primarily by employment opportunities with a logging company, Sylvicole de Bayanga, which operates a sawmill there. At its peak the logging company employed 600 full-time employees, and Bayanga's population swelled from several dozen to 5000 inhabitants in the 1970s. In 1986 bankruptcy halted logging operations and all workers were laid off. Bayanga's population declined to under 2000, although many people remained hoping to collect unpaid salaries and to be rehired when and if logging operations resumed.
Since 1988 the ICDP hired individuals elsewhere in the country and brought them to Bayanga, and also hired many local people who were former logging company employees. The ICDP employs approximately 50 fulltime staff and 25-70 temporary staff, the number depending on project funding levels. Logging operations resumed in 1993 with 120 full-time employees rehired by 1994, surpassing the ICDP as the major employer in Bayanga (Noss, 1995; under review).

Immigration inflates local populations and increases pressure on natural resources (Kremen et al., 1994; Metcalfe, 1994; Oates, 1995). People generally come to Bayanga to seek formal employment, preferably with the logging company. They do not come as agricultural colonists or commercial hunters, but those unable to find formal employment can meet their subsistence and economic needs by hunting, fishing and farming. They often abandon these activities when they are hired by the local company or the ICDP, but then employment provides salaries with which they can purchase meat and other forest products from their neighbours. Thus a town with only 150 formal jobs supports approximately 60 full-time cable-snare hunters, who sell 80 
per cent of the meat they produce through informal markets to consumers in Bayanga (Noss, in press a). Bayanga's 2500 residents depend on bushmeat (from wild game) for over 80 per cent of their meat consumption (not including fish), or over $100,000 \mathrm{~kg}$ of bushmeat per year (Noss, 1995).

The ICDP and commercial logging both encourage immigration, albeit at different rates. Furthermore, commercial logging cannot be separated from the ICDP, because sustainable commercial logging is one of the development activities permitted and promoted by the ICDP within the reserve portions of the protected area. The selective logging practised by Sylvicole de Bayanga could be ecologically sustainable, except that employment and economic development of this kind induce immigration, resulting in secondary effects of increasing the exploitative pressure on wildlife and other natural resources. The danger is that all other theoretically sustainable development activities, if they are successful in providing employment and raising incomes for local residents, will have the same effects.

The high degree of mobility also precludes a long-term commitment among local residents to a particular area, resource base or community (Ostrom, 1990). If local resources are exhausted people will move elsewhere to pursue other opportunities, as they have done in the past. A long-term commitment to a particular village or region does not dominate behaviour. Because they are not restricted to a specific resource base and defined territory, the costs to individuals of prudent resource use outweigh the benefits (Gadgil et al., 1993). People therefore seek to maximize short-term development benefits to themselves and their families, and ignore potential long-term benefits of conservation and sustainable, managed use. The short-term and intermittent natural resource exploitation practised by most individuals further precludes an awareness of long-term trends in wildlife populations or natural resource stocks. Conservation practices often result from perceptions of scarcity and decline, and are unlikely among people who lack these perceptions.

\section{Ethnic diversity}

The Bayanga region includes four major ethnic groups - the BaAka, Gbaya, Mbimu and Sangha-Sangha - as well as half-a-dozen other groups. The high degree of ethnic diversity results from the high residential and occupational mobility and the correspondingly high rate of immigration from other parts of CAR. Ethnic diversity tends to undermine community solidarity (Ostrom, 1990). Generally, loyalties are stronger within ethnic groups than across ethnic lines. Interethnic cooperation is therefore often difficult to achieve, because ethnic groups with different systems of natural resource exploitation and varying levels of dependence on natural resources also tend to disagree on management programmes and the distribution of benefits from development programmes (Lawry, 1990; Barrow et al., 1993a). Some groups may benefit from conservation, while others may lose (Brandon and Wells, 1992). Under such conditions, rational self-interested individuals will not act to achieve common or group interests (Olson, 1971; Ostrom, 1990).

Most relevant for conservation and development efforts in the Bayanga region is the BaAka/'Bilo' dichotomy, where the BaAka term 'Bilo' refers to all other ethnic groups. Assistance to one group is seen by the other as harm, resulting in jealousy and resentment. Thus, Bilo residents complain that foreigners only come to help the BaAka. For example, conservation legislation permits BaAka nethunting within the Dzanga-Sangha Reserve, while cable-snares are prohibited (as they are everywhere in the country, but enforcement only occurs where game guards are active). Net-hunting remains the most important hunting method for the BaAka, while Bilo residents depend primarily on cable-snares. Therefore, the ICDP's enforcement results in accusations from Bilo residents that the ICDP is 'forbidding us to eat' (Kretsinger, 1993).

The ICDP model depends on community participation in developing and managing conservation and development programmes. However, achieving community consensus on how to distribute benefits can be difficult even 
among relatively homogeneous communities. Thus, one of the most serious problems facing Zimbabwe's CAMPFIRE programme is the distribution of benefits from wildlife management among individuals of a single ethnic group within participating communities (Metcalfe, 1994). Bolivia's Kaa Iya del Gran Chaco National Park is administered by the popularly elected leadership of the 22 Izoceño Indian communities, yet one of the communities refuses to participate in any development activities undertaken by the leadership (Noss, unpublished observations).

In the ethnically diverse Bayanga region, benefit distribution becomes even more complex. In the absence of pre-existing organizations uniting the numerous villages and ethnic groups, the ICDP has attempted to create community institutions to address its development objectives and distribute revenues from tourism. Internal disagreements and misuse of funds caused the first to collapse: the Association Communautaire de Yobé-Sangha included representatives of employment guilds such as farmers, fishermen, market women and merchants (Hunsicker and Ngambesso, 1993). Its replacement, the Comité de Développement de Bayanga, founded in 1994, includes representatives from all Bayanga neighbourhoods and other nearby villages.

\section{Lack of resource tenure}

All land and natural resources in CAR are government-owned. Since colonial times local people have been ignored as governments award management and exploitation rights for vast areas to external organizations: concession companies in the 1890 s, commercial societies in the 1920s, logging companies since the 1970s, safari hunters in the 1980s and conservation organizations in the 1990s (Kalck, 1971; Zoctizoum, 1983; Colchester, 1993). Today a logging company, a safari-hunting company and a conservation organization all operate out of Bayanga, with overlapping jurisdictions and sometimes conflicting objectives.

Local people do not influence how con- cessions are awarded, nor are they able to exclude outsiders from exploiting the open access resources of the region. In addition to the large foreign organizations, diamond miners and commercial hunters also enter the region at will. Thus, if local residents do not hunt the animals, someone else will, and the people of Bayanga lack incentives to conserve resources for the future. Some anthropologists argue that this behaviour results from deeper cultural attitudes: according to Bird-David (1992a,b), 'hunter-gatherers' like the BaAka trust the environment to share its resources with them according to their needs, assuming abundance rather than scarcity. Other Central African ethnic groups, who may be described as 'hunter-horticulturists', view the environment in the same way (Guddemi, 1992). The natural environment is not something to be managed and owned, but rather it is one source of sustenance (additional sources in the modern context include other ethnic groups and external organizations). Resources cannot be owned until they are collected (Endicott, 1979).

Community conservation efforts in East Africa therefore incorporate land and resource tenure for local communities (Barrow et al., 1993b). But tenure does not mean that natural resources will be conserved, or that wildlife will be exploited sustainably: the economic costs of conservation may outweigh the benefits of long-term use (Feeny et al., 1990; Alvard, 1994). People's needs and expectations do not necessarily coincide with conservation objectives (Brandon and Wells, 1992; Robinson and Redford, 1994).

\section{Economic diversification}

The economic history of the Bayanga region is one of booms and busts: of ivory and wild rubber, then of coffee, then of timber, next possibly of tourism and diamonds. People must therefore adapt to changing circumstances, seizing opportunities. when they are available because they will not last. This is a long-term strategy for Bayanga residents who have moved to Congo to work in palm oil 


\section{A. J. NOSS}

plantations, then to Cameroon and other parts of CAR to work for logging companies. Diversification is also a short-term strategy for local residents, who shift on a daily or weekly basis among subsistence and economic activities. BaAka residents choose among net-hunting, gathering, fishing, farming, day labour for Bayanga residents and formal labour. Residents - of several ethnic groups - snare hunt, fish, farm, tap raffia wine, make raffia roof shingles, mine diamonds and work for the logging company or the ICDP.

Similar flexible, mixed economic strategies or 'opportunistic foraging' have been described elsewhere in tropical forests (Rambo, 1979, 1982; Griffin, 1981; Rai, 1982; Endicott and Bellwood, 1991; Jorgensen, 1995). In many cases wildlife exploitation represents an important component of these economic strategies, a 'subsidy from nature' that sustains rural populations in forest areas while they seek and engage in other economic activities (Redford, 1992, 1993). Rural households tend to choose diversification over resource management in labour allocation because diversification of economic activities protects the human system from collapse when major resources decline (Rambo, 1979; Goldman, 1995). In addition, by not committing themselves to any single long-term activity, people are always ready to take advantage of new and better opportunities that may arise (Endicott, 1979; Bird-David, 1992a,b; Sellato, 1994). An important component of diversified strategies is the high degree of mobility described above (Eder, 1984, 1988).

\section{Lack of a conservation ethic}

Neither the BaAka nor the Bilos exhibit a 'conservation ethic' in their exploitation of natural resources. Like most other peoples of the world they are consumers rather than conservationists, although historically resource exploitation methods combined with low population pressure and mobility precluded overexploitation. Hunters are 'opportunistic predators' rather than conservationists (Hames, 1991; Lahm, 1993; Alvard, 1994): they capture as many animals of any species, sex and age as they can (Noss, in press $a$, b; under review), because any meat that is not eaten can be sold, and meat that cannot be sold is eaten. In Bird-David's terms (1992a,b), they 'procure' resources from the environment, taking whatever they see. Snare-hunters always want additional snares. Net-hunts that are very successful are never cut short because enough animals have been captured; instead, hunters often push on longer because tomorrow might not be so successful (Noss, 1995; in press b).

Local residents are not concerned that exploitation be sustainable in the long term because they will switch to other resources that become valuable at a later date, or to other activities in the suite that they pursue simultaneously. In Cameroon, hunters stated that they were not concerned about wildlife extinctions because they did not expect their children would have to hunt (Infield, 1988). By the time their children grow up, economic development will provide alternatives to hunting. If necessary, people can move elsewhere, even as they migrated to Bayanga in the first place. Because they do not own the land or the resources they exploit, they do not forfeit anything by moving away.

An important characteristic of opportunistic foraging is the relative lack of management costs: resources are harvested or 'mined' rather than managed. The only costs incurred in hunting are the capital investment in equipment and the time investment, both of which are low. For example, the capital investment in an entire cable-snare line can be recouped by the sale of two duikers (Cephalophus spp.), the average return for less than 2 weeks of hunting. The opportunity costs of time for rural residents are generally extremely low (Barrett and Arcese, 1995). Employment and income-producing alternatives to natural resource exploitation are scarce and returns to labour are low.

Although they may result in more sustainable long-term exploitation, the adoption of resource management practices of any kind imposes additional short-term costs (Alvard, 1994). In Bayanga, elephants and other 
animals destroy crops, while the ICDP game guards arrest local hunters, confiscate their property and restrict Bayanga residents in pursuing other activities as well, for example diamond mining and farming. People are unwilling to bear these management conservation costs in the absence of significant short-term benefits because, under prevailing conditions of low returns, additional costs of production are difficult to recoup. Evaluations of community-based conservation efforts find that for most individuals the economic benefits from illegal resource exploitation exceed those produced by the project's economic development activities (Durbin and Ralambo, 1994; Gibson and Marks, 1995). Management and conservation are not in their economic self-interest (Wells and Brandon, 1993). Furthermore, rural populations are not concerned about declines in natural resources because they do not depend solely on natural resources such as wildlife and therefore do not perceive declines as risks (Kottak and Costa, 1993).

\section{Discussion}

Together, these challenges undermine the assumption of 'community' upon which ICDPs and community conservation concepts are based and represent fundamental obstacles to efforts to create a 'community' supportive of conservation efforts. In some cases, it may be possible for conservation and development organizations to address these challenges. Most importantly, programmes that include development components must seek to restrict immigration of individuals attracted to new economic opportunities. However, it may be exceedingly difficult, particularly for an external organization, to restrict people's movements within their own country, particularly when they seek to join family members. Nevertheless, the approach may be successful in the Ndoki-Nouabalé project in Congo, where the Bomassa village council must approve any permanent settlement. In return, however, the project provides employment for all 50 adult males, and full employment is not possible just $80 \mathrm{~km}$ upriver in Bayanga, where there are 500 adult males.

Fundamental to Zimbabwe's CAMPFIRE success is the granting of tenure over land and wildlife to individual ranch owners and rural communities (Metcalfe, 1994). This is possible where land boundaries can be clearly demarcated, where the returns from wildlife conservation can be demonstrated immediately and where communities are relatively homogeneous. Implementation of such a programme involving the allocation of rights to natural resource exploitation among competing groups is considerably more difficult in cases like Bayanga with a large, dynamic and multiethnic population. Furthermore, most Bayanga residents prefer the economic development and formal employment associated with logging to what they have seen from conservation (Kretsinger, 1993). Previous experiences with a logging company, subsidized by the Yugoslav Government between 1972 and 1986, raised expectations among Bayanga residents. In addition to employment, the company provided housing and transport, as well as health and education services, and they did not restrict hunting. Nether the ICDP nor the current French logging operation meet these expectations. In fact, community participation models expect people to take responsibility for and contribute to their own development.

In Zimbabwe, the National Parks and Wildlife Service cannot keep up with requests from rural communities wishing to join the CAMPFIRE programme. Similarly, Bodmer (1994) described a case in Peru where the community began to prohibit outsiders from exploiting wildlife resources, and asked for government and international assistance in establishing a protected area where wildlife exploitation could be managed. In CAR, people ask for logging companies.

In order to counter cultural tendencies to diversify economic and subsistence strategies that include natural resource exploitation, conservation programmes seek to introduce economically sustainable activities. But a recent evaluation found that few ICDPs had identified viable long-term alternatives to resource use (Wells et al., 1992). Cultural 


\section{A. J. NOSS}

tendencies may not change easily because they result from a history of economic booms and busts in an uncertain and changing environment, where human survival depends on the ability to adapt to change as opportunities come and go. People may see reductions in access to wildlife and other natural resources as threats to their economic security.

At the same time, the fact that wildlife exploitation represents only one component of diversified economic strategies suggests that it may not be indispensable to rural residents (Noss, 1995, 1997). Conservation programmes may therefore be able to replace wildlife use with activities that are more compatible with conservation objectives.

However, development of any kind near protected areas induces immigration (or discourages emigration), fosters population growth and raises expectations among local residents (Southgate and Clark, 1993; Oates, 1995). All of these factors tend to increase exploitative pressure on natural resources, particularly where such exploitation has long sustained rural populations.

Finally, in the absence of a single unified 'community' with which conservation organizations can collaborate, the latter can seek to create community organizations with a broad, multiethnic constituency for conservation. But they should understand the obstacles that this process must overcome: mobile populations, lack of resource tenure, patterns of economic diversification, ethnic diversity and the lack of a conservation ethic. As a result, some critics suggest that attempting to change behaviour towards support for conservation efforts by providing economic benefits to communities may be an inappropriate strategy in rural Africa (Gibson and Marks, 1995).

\section{Conclusion}

Facing these challenges in central African forests, the concepts of integrated conservation and development and community conservation are therefore in serious jeopardy. Development is necessary to provide alternative subsistence and economic opportunities for local residents, so that they depend less on natural resource exploitation. But development induces immigration and raises expectations above and beyond the capacity of a conservation project's development components to provide employment and meet economic needs. Immigrants historically combined hunting and gathering with other subsistence and economic activities, and when they continue to do so within or near protected areas they significantly increase pressure on natural resources. The lack of tenure results in open access resources that are exploited by all and managed by none. The historical pursuit of diversified economic strategies means that rural residents are reluctant to relinquish access to wildlife and other natural resources. Ethnic diversity undermines the community solidarity necessary for co-operative resource management.

These challenges can be addressed though conservation programmes, but conservationists and donors should recognize that fundamental socio-economic change will be necessary in many cases where stable and homogeneous communities, long-term economic opportunities and a conservation ethic do not exist. A conservation project that includes community development components may not find a community or may find that successful development undermines its conservation objectives.

\section{Acknowledgements}

Research was assisted by a grant from the Joint Committee on African Studies of the Social Science Research Council and the American Council of Learned Societies with funds provided by the Ford, Mellon and Rockefeller Foundations. Additional funds were provided by two Grants-in-Aid of Research from Sigma Xi, The Scientific Research Society; and by the World Wildlife Fund under the United States Department of Agriculture Agreement No. 93-G-155. Three anonymous referees provided helpful comments on the manuscript.

\section{References}

Alvard, M.S. 1994. Conservation by native peoples: prey choice in a depleted habitat. Human Nature, 5, 127-154.

(C) $1997 \mathrm{FFI}$, Oryx, 31 (3), 180-188 
Barrett, C.B. and Arcese, P. 1995. Are integrated conservation-development projects (ICDPs) sustainable? On the conservation of large mammals in sub-Saharan Africa. World Development, 23, 1073-1084.

Barrow, E., Bergin, P., Infield, M. and Lembuya, P. 1993a. Community Conservation: Lessons from Benefit Sharing in East Africa. In Integrating People and Wildlife for a Sustainable Future (eds J.A. Bissonette and P. R. Krausman), pp. 21-26. The Wildlife Society, Bethesda, Maryland.

Barrow, E., Bergin, P., Infield, M. and Lembuya, P. 1993b. The People's Voice: Partnership and Community Conservation. In Integrating People and Wildlife for a Sustainable Future (eds J. A. Bissonette and P. R. Krausman), pp. 255-259. The Wildlife Society, Bethesda, Maryland.

Bird-David, N. 1992a. Beyond the 'hunting and gathering mode of subsistence': culture-sensitive observations on the Nayaka and other modern hunter-gatherers. Man, 27, 19-44.

Bird-David, N. 1992b. Beyond the 'original affluent society': a culturalist reformulation. Current Anthropology, 33, 25-47.

Bodmer, R.E. 1994. Managing wildlife with local communities in the Peruvian Amazon: the case of the Reserve Comunal Tamshiyacu-Tahuayo. In Natural Connections: Perspectives in Communitybased Conservation (eds D. Western and R. M. Wright), pp. 113-134. Island Press, Washington, DC.

Brandon, K.E. and Wells, M. 1992. Planning for people and parks: design dilemmas. World Development, 20, 557-570.

Colchester, M. 1993. Slave and enclave: towards a political ecology of equatorial Africa. The Ecologist, 23, 166-173.

Durbin, J.C. and Ralambo, J.A. 1994. The role of local people in the successful maintenance of protected areas in Madagascar. Environmental Conservation, 21, 115-120.

Eder, J.F. 1984. The impact of subsistence change on mobility and settlement pattern in a tropical forest foraging economy: some implications for archaeology. American Anthropologist, 86, 837-853.

Eder, J.F. 1988. Batak foraging camps today: a window to the history of a hunting-gathering economy. Human Ecology, 16, 36-55.

Endicott, K. 1979. The impact of economic modernisation on the Orang Asli (aborigines) of northern peninsular Malaysia. In Issues in Malaysian Development (eds J. C. Jackson and M. Rudner), pp. 167-204. Heinemann, Singapore.

Endicott, K. and Bellwood, P. 1991. The possibility of independent foraging in the rain forest of peninsular Malaysia. Human Ecology, 19, 151-185.

Feeny, D., Berkes, F., McCay, B.J. and Acheson, J.M.
1990. The tragedy of the commons: twenty-two years later. Human Ecology, 13, 1-19.

Gadgil, M., Berkes, F. and Folke, C. 1993. Indigenous knowledge for biodiversity conservation. Ambio, 22, 151-156.

Gibson, C.C. and Marks, S.A. 1995. Transforming rural hunters into conservationists: an assessment of community-based wildlife management programs in Africa. World Development, 23, 941-957.

Goldman, A. 1995. Threats to sustainability in African agriculture: searching for appropriate paradigms. Human Ecology, 23, 291-334.

Griffin, P.B. 1981. Northern Luzon Agta subsistence and settlement. Filipinas, 2, 26-42.

Guddemi, P. 1992. When horticulturalists are like hunter-gatherers: the Sawiyano of Papua New Guinea. Ethnology, 31, 303-314.

Hames, R.B. 1991. Wildlife conservation in tribal societies. In Biodiversity: culture, conservation and ecodevelopment (eds M. L. Oldfield and J. B. Alcorn), pp. 172-199. Westview, Boulder.

Hunsicker, P.M. and Ngambesso, F. 1993. Banking on a nature reserve. In The Law of the Mother: Protecting Indigenous Peoples in Protected Areas (ed. E. Kemf), pp. 233-237. Sierra Club Books, San Francisco.

Infield, M. 1988. Hunting, Trapping and Fishing in Villages within and on the periphery of the Korup National Park. Paper No. 6 of the Korup National Park socio-economic survey. World Wide Fund for Nature. Unpublished manuscript.

Jorgensen, J.P. 1995. Maya subsistence hunters in Quintana Roo, Mexico. Oryx, 29, 49-57.

Kalck, P. 1971. Central African Republic: A Failure in De-colonisation. Praeger, New York.

Kottak, C.P. and Costa, A.C.G. 1993. Ecological awareness, environmentalist action and international conservation strategy. Human Organization, 52, 335-343.

Kremen, C., Merenlender, A.M. and Murphy, D.D. 1994. Ecological monitoring: a vital need for integrated conservation and development programs in the tropics. Conservation Biology, 8, 388-397.

Kretsinger, A. 1993. Some Development Options for the BaAka within the Dzanga-Sangha Dense Forest Reserve. World Wildlife Fund, Bayanga. Unpublished report.

Lahm, S.A. 1993. Ecology and economics of human/wildlife interaction in northeastern Gabon. PhD thesis. New York University, New York.

Lawry, S.W. 1990. Tenure policy toward common property natural resources in sub-Saharan Africa. Natural Resources Joumal, 30, 403-422.

Metcalfe, S. 1994. The Zimbabwe Communal Areas Management Programme for Indigenous Resources (CAMPFIRE). In Natural Connections: Perspectives in Community-based Conservation (eds 
D. Western and R. M. Wright), pp. 161-192. Island Press, Washington, DC.

Noss, A.J. 1997. The economic importance of communal net hunting among the BaAka of the Central African Republic. Human Ecology, 25, 71-89.

Noss, A.J. In press a. Cable snares and nets in the Central African Republic. In Sustainability of Hunting in Tropical Forests (eds J. G. Robinson and E. Bennett).

Noss, A.J. In press b. The impacts of cable snare hunting on wildlife populations in the forests of the Central African Republic. Conservation Biology.

Noss, A.J. Under review. The Aka of the Central African Republic. In African Rain Forest Ecology and Conservation (eds W. Weber, A. Vedder, $\mathrm{H}$. Simons Morland, L. White and T. Hart).

Noss, A.J. 1995. Duikers, cables and nets: a cultural ecology of hunting in a central African forest. PhD thesis, University of Florida, Gainesville.

Oates, J.F. 1995. The dangers of conservation by rural development - a case study from the forests of Nigeria. Oryx , 29, 115-122.

Olson, M. Jr. 1971. The Logic of Collective Action: Public Goods and the Theory of Groups. Schocken, New York.

Ostrom, E. 1990. Governing the Commons: The Evolution of Institutions for Collective Action. Cambridge University Press, Cambridge.

Rai, N.K. 1982. From forest to field: study of Philippine Negrito foragers in transition. PhD thesis, University of Hawaii, Honolulu.

Rambo, A.T. 1979. Human ecology of the Orang Asli: a review of research on the environmental relations of the aborigines of peninsular Malaysia. Federations Museums Journal, NS 24, 41-71.

Rambo, A.T. 1982. Orang Asli adaptive strategies: implications for Malaysian natural resources development planning. In Too Rapid Rural Development: Perceptions and Perspectives from Southeast Asia (eds C. MacAndrews and C. L.
Sien), pp. 251-299. Ohio University Press, Athens.

Redford, K.H. 1992. The empty forest. BioScience, 42, 412-422.

Redford, K.H. 1993. Hunting in neotropical forests: a subsidy from nature. In Tropical Forests, People and Food: Biocultural Interactions and Applications to Development (eds C. M. Hladik, A. Hladik, O. F. Linares, H. Pagezy, A. Semple and M. Hadley), pp. 227-246. UNESCO, Paris.

Robinson, J.G. and Redford, K.H. 1994. Communitybased approaches to wildlife conservation in neotropical forests. In Natural Connections: Perspectives in Community-based Conservation (eds D. Western and R. M. Wright), pp. 300-319. Island Press, Washington, DC.

Sellato, B. 1994. Nomads of the Borneo Rainforest: the Economics, Politics and Ideology of Settling Down. University of Hawaii Press, Honolulu.

Southgate, D. and Clark, H.L. 1993. Can conservation projects save biodiversity in South America? Ambio, 22, 163-166.

Stocking, M. and Perkin, S. 1992. Conservationwith-development: an application of the concept in the Usambara Mountains, Tanzania. Transactions of the Institute of British Geographers, NS 17, 337-349.

Wells, M.P. and Brandon, K.E. 1993. The principles and practice of buffer zones and local participation in biodiversity conservation. Ambio, 22, 157-162.

Wells, M, Brandon, K. and Hannah, L. 1992. People and Parks: Linking Protected Area Management with Local Communities. World Bank, Washington, DC.

Western, D. and Wright, R.M. (eds) 1994. Natural Connections: Perspectives in Community-based Conservation. Island Press, Washington, DC.

Zoctizoum, Y. 1983. Histoire de la Centrafrique. Harmattan, Paris.

Andrew J. Noss, Wildlife Conservation Society, Casilla 2417, Santa Cruz, Bolivia. 